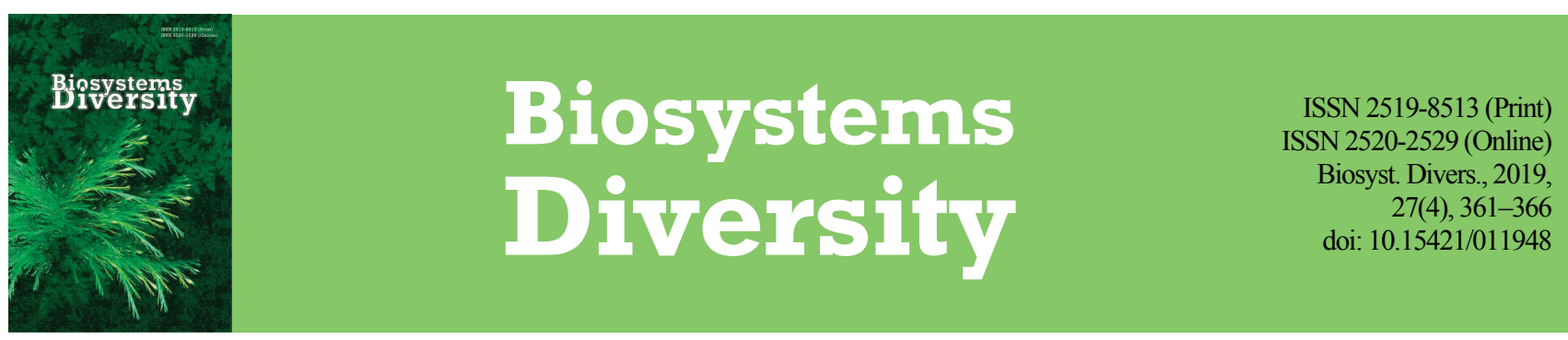

\title{
Dynamic phase portrait: New possibilities of detecting changes in populations
}

\author{
V. G. Tereshchenko*, E. I. Boznak**, L. I. Tereshchenko* \\ *Papanin Institute for Biology of Inland Waters Russian Academy of Sciences, Borok, Russia \\ **Institute of Biology of Komi Science Centre of the Ural Branch of the Russian Academy of Sciences, Syktyvkar, Russia
}

Article info

Received 18.08.2019

Received in revised form 20.09.2019

Accepted 21.09.2019

Papanin Institute for Biology of Inland Waters Russian Academy of Sciences, Borok Yaroslavl reg., Russia. Tel.: 485-472-40-42. E-mail:tervlad@ibiw.ru

Institute of Biology of Komi Science Centre of the Ural Branch of the Russian Academy of Sciences, Kommunisticheskaya st., 28 Syktyvkar, 167000, Russia. Tel.: +7-821-224 52-02.E-mail: boznak@ib.komisc.ru

\author{
Tereshchenko, V. G., Boznak, E. I., \& Tereshchenko, L. I. (2019). Dynamic phase portrait: New possibilities of \\ detecting changes in populations. Biosystems Diversity, 27(4), 361-366. doi:10.15421/011948
}

This paper demonstrates the possibilities of detecting changes in populations of animals, based on the analysis of their dynamic phase portrait. This method allowed us to clarify the periodization of the process of naturalization of the Black Sea sprat (Clupeonella cultriventris) in the Rybinsk Reservoir and in detail describe the changes in the main dynamic characteristics of the population. On the example of zander (Sander lucioperca) in Lake Vozhe, the state was observed in which intra-population mechanisms activate which slow the increase in population (distribution of individuals from regions with high density). Use of this method allowed us to describe the new stable state of the population of grayling (Thymallus thymallus), which it entered as a result of increase in sport fishing. The data on time of presence of a population in equilibrium state allowed us to correctly unify the materials used for the analysis of changes in its age group.

\section{Keywords: equilibrium condition; number; age structure; invader; potential speed of growth; fish.}

\section{Introduction}

The ability to resist the external impact or return to the initial state after disturbance is an ability characteristic and necessary for all biological systems at all levels of the organization. In ecology, the analysis of disturbances is an experimental tool which allows one to determine how a complex system functions, because at that time the capabilities of separate elements as well as connections between them manifest more clearly (Begon et al., 1986; Clarke \& Warwick, 1998). The changes in the community are known to be conditioned by changes in the population characteristics of the species which form it, i.e. abundance, age and sex structures, fertility, mortality, etc. (Bobretsov, 2009; Gerasimov et al., 2010, 2013; Boonstra \& Krebs, 2012; Rozenfeld \& Sheremetyev, 2016). It is important to note that changes in characteristics of populations occur over a certain time due to consequent alterations. Therefore, its reaction to external factors to a large extent depends on inertia (Romanovsky et al., 1975), and is related to complex dynamic systems (Antamonov, 1977). One of effective methods of analyzing such a system is the survey of its dynamic phase portrait (Vol'kenshtein, 1978).

In ecology, analysis of changes in populations and communities in phase space is common (the socalled parametric phase portrait Odum, 1971), which uses a set of parameters as coordinates; for example, number of separate species, production, biomass, etc. (Gilpin et al., 1982; Knut, 1997; Portrait et al., 1999). A distinctive feature of the dynamic phase portrait method is the analysis of dynamics of the system within the space of its states, which are determined on the one hand by the parameter significant for its functioning (for example, number, structural parameter, density, biomass, etc.) and on the other hand by speed characteristics (rate, acceleration) of change in this parameter. The simplest case includes two such variables: one of the coordinates is a parameter, and the other is the rate of its change. Taking into account the rate at which the changes occur makes it possible to reveal the condition and assess the pattern of dynamics of population or community during deviation from them. At the same time, we can predict changes in a system on the basis of this information.

Dynamic phase portraits developed for analyzing real biological systems not on the basis of mathematical model, but on the empirical data have demonstrated their efficiency for survey of both real communities of hydrobionts (Tereshchenko \& Tereshchenko, 2004; Tereshchenko \& Strelnikov, 1995, 1997; Tereshchenko \& Nadirov, 1996; Polovkova et al., 2007; Tereshchenko et al., 2007; Reshetnikov et al., 2011; Dorovskikh et al., 2012, 2016; Mineeva \& Tereshchenko, 2013), and real populations (Tereshchenko et al., 2015, 2016a, b; Tereshchenko \& Tereshchenko, 2017; Boznak et al., 2019).

This approach allowed new data to be obtained on the capabilities of a population and changes in its structural-functional characteristics, which occur under the influence of natural and anthropogenic factors. Therefore, for naturalization and successful colonisation of a territory, it is necessary not only for individuals of invasive species to survive the new conditions, but also for its population to have dynamic characteristics which allow it to rapidly increase in number. The assessment of such parameters was performed for few species of fish which settled in the Volga and Dnieper cascades and formed there numerous self-reproducing populations (Slynko \& Kiyashko, 2012; Slynko \& Tereshchenko, 2014; Tereshchenko et al., 2015, 2016a, b; Tereshchenko \& Tereshchenko, 2017).

During the process of growth of a population, the moment occurs, when the mechanisms of density regulation are activated. The possibility of assessment of a density at which the mortality was higher than birth rate and emigration of individuals from the regions with high density was observed is demonstrated on the example of zander (Sander lucioperca) introduced into Lake Vozhe (Tereshchenko \& Zuyanova, 2006).

Changes in the parameters of population may be caused and intensified by anthropogenic load. On the example of lavaret (Coregonus lavaretus) and grayling (Thymallus thymallus) (Linnaeus, 1758) in one of the watercourses of the Middle Timan, it has been demonstrated that as a result of the development of the road system, even in the absence of notable changes in the environment, intensification of sport fishing can lead to decrease in the number and change in the structure of populations of valuable fish species (Boznak et al., 2019).

The objective of this study was to generalise the experience of using dynamic phase portrait for analysis of populations of fish, thus revealing the possibilities of the method to reveal additional information about biochanges in them. 


\section{Materials and methods}

Assessments of the characteristics of the populations of the studied species, development of dynamic phase portraits and the following analysis of the results was performed on the basis of materials collected using standard methods. The assessment of the speed of changes in the number of Black Sea sprat (Clupeonella cultriventris) and European smelt (Osmerus eperlanus (L.)) was based on the data of their abundance in the catch by the survey trawl (Tereshchenko et al., 2015; Tereshchenko \& Tereshchenko, 2017). The information from different sources was standardized, providing records for $15 \mathrm{~min}$. of trawling. Relative number of grayling (Thymallus thymallus) was calculated as a value of caught fish per attempt, i.e. number of individuals caught in a standard net of $30 \mathrm{~m}$ length during $24 \mathrm{~h}$ (Boznak et al., 2019). Study on the dynamics of the number of population of zander (Sander lucioperca) in Lake Vozhe was based on the data on the catch over the year. Since in that water body, during the period of study, the level of industrial effort was stable, and the record of fish production was well main-tained, the change in the amount of caught fish reflected the change in abundance of the species. In the study, the multi-years dynamics of the caught fish per attempt for each species was analyzed.

In ecology, for the calculation of the rates of growth of population, apart from increase in abundance per unit time, the following parameters are taken into account as potential and specific rates of population growth. Specific rate of changes in the abundance of a population, which characterizes the increase in abundance per unit time, was calculated using the formula (Birch, 1948; Odum, 1971; Pianka, 1978; Voronov, 2005):

$$
r_{N}=\left(\ln N_{t 2}-\ln N_{t 1}\right) /\left(t_{2}-t_{1}\right),
$$

where $N_{t 1}$ и $N_{t 2}$ - density of population of animals in the moments of time $t_{1}$ and $t_{2}$ (years).

Maximum value of specific rate of change in number, observed with exponential growth of population, is called "potential rate of growth" (and also "biotic potential" or "reproductive potential"). It characterizes the intrinsic - conditional property of a species to increase in number in a particular habitat (Odum, 1971; Pianka, 1978; Solbrig \& Solbrig, 1979).

To answer the questions whether a population or community is in a condition of equilibrium and when the system has changed from one steady state to another, its "dynamic phase portrait" was analyzed (Vol'kenshtein, 1978; Svirizhev \& Logofet, 1978). Methods of developing a phase portrait of real above-organism systems was described earlier (Verbitsky \& Tereshchenko, 1996; Tereshchenko \& Verbitsky, 1997). Here, we should note that for the analysis of fish populations, changes in the coordinates $N$ and $d N / d t$, were analyzed, where $N$ - relative number (caught fish per attempt), $d N / d t$ - speed of its change.

An important aspect of developing dynamic phase portraits of real populations or communities is preliminary smoothing of initial data of the analyzed parameter, which is necessary for reduction of the influence of random fluctuations. For this purpose, the entire temporal interval of observations was divided into 500 sections and approximated using a parabolic window and the initial data were interpolated. The latter operation allows reduction of errors in speed of change in the parameter. As our experiment has shown, good results are also provided by smoothing by the method of spline interpolation, though on the boundaries of interval of study the first method of smoothing works better.

The following analysis was based on the search for steady or equilibrium zones, in which the rate of changes in the number of animals was close to zero. The indicator of the reaction of population to disturbance is transition into another state of balance or disturbance of graduality of the phase portrait curve. A dynamic phase portrait of a system (population or community), far deviating from the equilibrium state, looks like convex or concave arc orientated from the initial state to new state. At the same time, over the process of formation, at first acceleration in the restructurisations is observed (increase in the rate of change in the studied parameter by module), and at the second stage - their slowing. In state of equilibrium the amplitude of fluctuations of the parameter is minimum, and the trajectory of movement of the system on the phase portrait looks like a inwardcoiling spiral - a special point "stable focus", and in the case of an uncoiling spiral - a special point "non-stable focus" or elliptic curve of small amplitude - special point "center" (Verbitsky \& Tereshchenko, 1996; Tereshchenko \& Verbitsky, 1997).

\section{Results}

Changes in the formation of population of an invasive species. As an example, we shall consider the process of naturalization of Black Sea sprat in the Rybinsk Reservoir located 1,000 km to the north of its native range. It was first recorded there in 1994 (Tereshchenko \& Strelnikov, 1997). In a new environment, a new species undergoes consequent phases of naturalization: introduction or penetration (phase I), reproduction (phase II), the colonisation of the territory and increase in abundance (phase III), functioning in the regime of fluctuation of number (phase IV) (Karpevich, 1975; Odum, 1971; Inderjit et al., 2005).

According to a number of authors (Kiyashko \& Slynko, 2003; Gerasimov, 2005; Kiyashko et al., 2006) in 1998-2002 in the reservoir, constant growth in the amount of caught sprat was observed (Fig. 1) $10-530 \mathrm{spec} / 15 \mathrm{~min}$ of trawling. At the same time (phase III) the maximum specific rate in growth of its population equaled $r_{\text {Nmax }}=2.10$ year $^{-1}$ (Slynko \& Kiyashko, 2012; Slynko \& Tereshchenko, 2014). The dynamic phase portrait in that period looked like a convex arc, indicating the process of formation of the population. In early 2000s, the trajectory of change in the number became cyclic with small amplitude of fluctuation (Fig. 1b), i.e. the population entered the state of equilibrium with average number of caught individuals equaling $500 \mathrm{spec} / 15 \mathrm{~min}$ of trawling. Therefore, the third phase of the invader's naturalization - phase of exponential growth of number - took place between 1998 to 2002. The average specific rate of change in the number of sprat in that phase was 1.26 year $^{-1}$

In 2003-2004 the pattern of growth of the sprat population changed (a critical point was observed) and further the trajectory of the movement of the population moved back from cyclic to concave arc (Fig. 1b). At that time, the species was in the IV phase, naturalization (Slynko \& Kiyashko, 2012), average specific rate of change in abundance remained at the same level as in the previous stable state, though its variability increased (Tale 1). Against the background of overall growth in the abundance of sprat, a short period of slowing of the speed of this process was observed.

Table 1

Dynamic parameters of population of Black Sea sprat in the Rybinsk Reservoir (according to Slynko \& Tereshchenko, 2014)

\begin{tabular}{|c|c|c|c|c|c|}
\hline \multirow[t]{2}{*}{ Years } & \multirow{2}{*}{$\begin{array}{c}\text { Phase of } \\
\text { natura- } \\
\text { lization }\end{array}$} & \multicolumn{3}{|c|}{$\begin{array}{l}\text { Specific rate of changes in the number } \\
\text { of population, year }{ }^{-1}\end{array}$} & \multirow[t]{2}{*}{$\mathrm{CV}, \%$} \\
\hline & & average & maximum & minimum & \\
\hline 1994 & I & - & - & - & - \\
\hline $\begin{array}{l}1995- \\
1997\end{array}$ & II & 0.13 & - & - & - \\
\hline $\begin{array}{l}1998- \\
2002\end{array}$ & III & $\begin{array}{l}1.30 \\
1.30\end{array}$ & $\begin{array}{l}2.10 \\
2.10 ;-\end{array}$ & $\begin{array}{c}0.51 ; \\
\underline{0.51 ;-}\end{array}$ & $\begin{array}{l}68 \\
68\end{array}$ \\
\hline $\begin{array}{c}2003- \\
2006\end{array}$ & IVa & $\begin{array}{c}1.20 \\
1.10 ; 1.30\end{array}$ & $\begin{array}{c}2.10 \\
2.10\end{array}-1.70$ & $\begin{array}{c}0.04: \\
0.04 ;-0.84\end{array}$ & $\begin{array}{c}\overline{78} \\
130 ; 49\end{array}$ \\
\hline $\begin{array}{c}2007- \\
2012 \\
\end{array}$ & $\mathrm{IVb}$ & $\begin{array}{c}1.60 ; \\
2.30 ; 1.20 \\
\end{array}$ & $\begin{array}{c}3.20 ; \\
3.20 ;-2.10 \\
\end{array}$ & $\begin{array}{c}0.46 ; \\
1.50 ;-0.46\end{array}$ & $\begin{array}{c}58 ; \\
51 ; 53 \\
\end{array}$ \\
\hline
\end{tabular}

Note: variants of calculation of rate - by module- regular font, cases of increasing abundance - underlined, and decrease in italics.

After 2006, the pattern of dynamics of abundance of the population changed again. In the phase portrait the concave arc morphed into an inward-winding spiral, indicating a new stable state which corresponded to the catch of $1300 \mathrm{spec} / \mathrm{min}$ of trawling. Thus, we can state the beginning of the next stage - naturalization phase IVb. The average specific rate of change in the population in the stable state increased. At the same time, both rates of increase and decrease in abundance increased (Table 1). As a result, cyclic fluctuations were observed, the amplitude of which was bigger than in the previous equilibrium state (Fig. 1).

Changes in the population of an introduced species. Zander, which was introduced into Lake Vozhev in 1987, successfully naturalized and became an industrial species (Bolotova et al., 1995). Until the early 2000s, the number of caught zander was continuously increasing (Fig. 2). However, the rate of this growth did not remain constant. The analysis of the dynamic phase portrait indicated that at least twice (1997-1998, and in 2001) the rate of increase in the population of zander notably slowed (Fig. 3). The further study of dynamics of separate generations of zander revealed 
that all generations born in 1993-1996 were numerous, and generations born in 1997-1999 were not (Tereshchenko \& Zuyanova, 2006). In other words, by the late 1990s, in the lake, the consequences of overpopulation of zander were observed. Its role in decrease in the rate of growth of the catch in 1997 and 2001 could have been played by its self-distribution from Lake Vozhe to the adjacent lake-river system, including the rivers and lakes of Archangelsk Oblast (Novoselov, 2003).
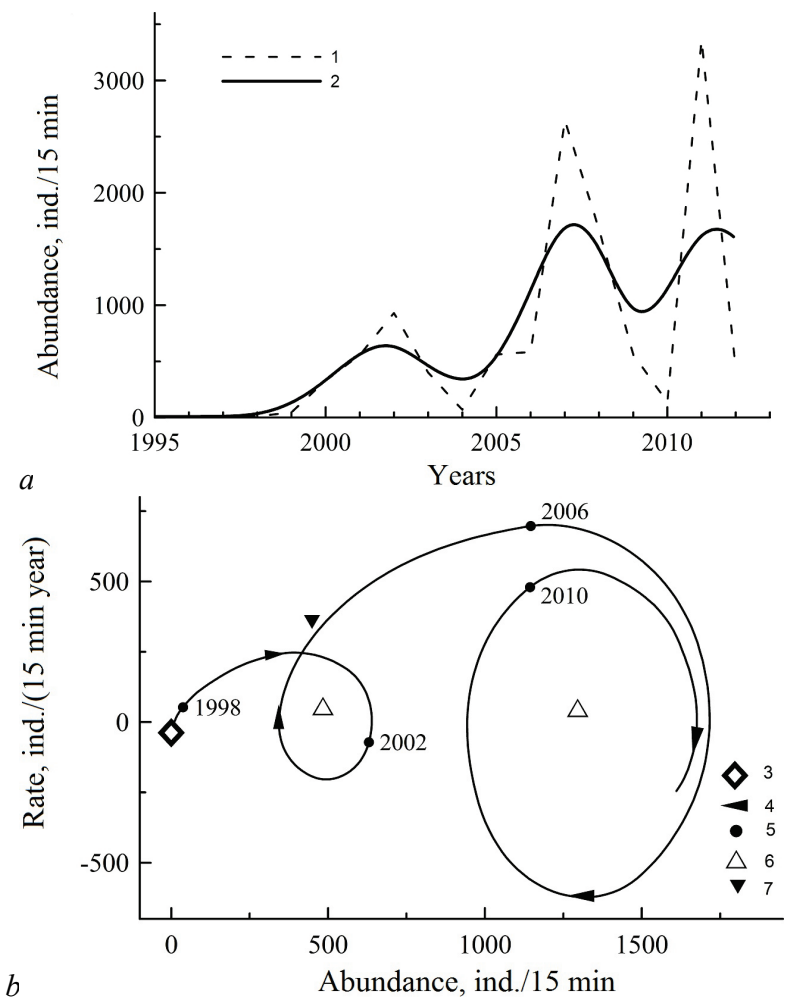

Fig. 1. Dynamics of abundance of Black Sea sprat in the Rybinsk Reservoir $(a)$ and its dynamic phase portrait $(b)$ (according to Slynko \& Tereshchenko, 2014): 1 - initial data; 2 - smoothened data; 3 - initial state; 4 -direction of shift of the system; 5 - state of population in the year indicated near the curve; 6 - stable state; 7 -critical point

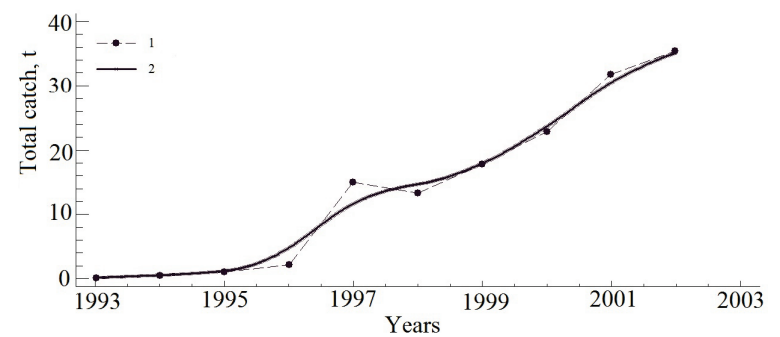

Fig. 2. Dynamics of zander catch in Lake Vozhe (according to Bolotova et al., 1995): 1 - initial data; 2 - smoothened data with "window" of 1.1 year

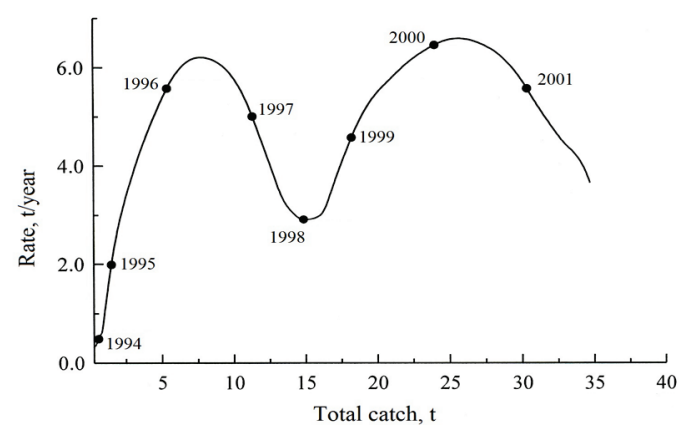

Fig. 3. Dynamic phase portrait of zander catch in Lake Vozhe (according to Tereshchenko \& Zuyanova, 2006): the numbers on the curve are years of population being in the state indicated by the point on the curve
Changes in population under the effect of intense sport fishing. As an example, we shall consider the population of grayling (Thymallus thymal$l u s)$ in the upper stream of the Vym River in the conditions of influence of poorly-controlled non-commercial fishing. During the period of observations, its relative number changed within 1.5-6.7 spec/net/day with the period of fluctuations equaling 4 years.

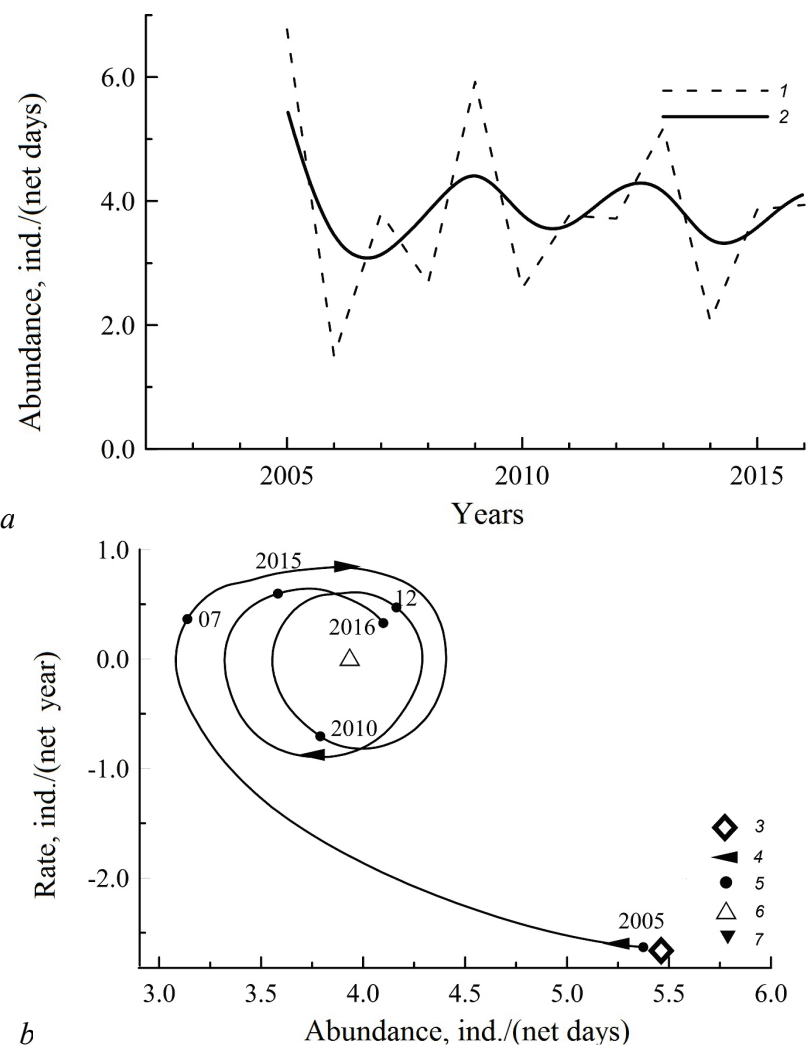

Fig. 4. Dynamics of abundance $(a)$ and dynamic phase portrait $(b)$ of population of grayling in the Vym River (according to Boznak et al., 2019): 1 - initial data; 2 - smoothened data; 3 - initial state of population; 4 - direction of its shift; 5 - condition in year indicated near; 6 - stable state; 7 -critical point in functioning

At general tendency of reduction, the amplitude of these fluctuations decreased as well: in 2005-2007 it was 2 spec./net, in 2009-2016 was not higher than $1 \mathrm{spec} /$ net (Fig. 4). At this point the possibilities of traditional description of changes are exhausted.

The analysis of dynamic phase portrait was notably more informative. In 2005, the relative number of population of zander equaled $5.5 \mathrm{spec} . \mathrm{net}$. At that time, the rate of changes in abundance was negative, being maximum (by module) throughout the entire period of observations, which is characteristic of the system in the state of restructuring (Fig. 4b). By 2007, the rate of changes in the population (according to the module) decreased to $1.0 \mathrm{spec}$. net/year, and its trajectory now looked like an inward-winding spiral. In other words, in 2005-2007, the population of zander entered into equilibrium state which corresponded to average amount of the fish caught of $4.0 \mathrm{spec} /$ net (special point "stable focus"), in which it remained until 2016. In this steady condition, the populations are characterized by only cyclic fluctuations in abundance with reduction in their amplitude.

\section{Discussion}

The abovementioned examples show that use of the method of dynamic phase portrait allows efficient determination of the most significant changes occurring in the population over the process of its formation and functioning. The main (but not the only) advantage of this method is the possibility of distinguishing a population in the phase of restructurization of its structural-functional characteristics from a population in the state of equilibrium without any notable changes in the main structural parameters and pattern of its functioning. At the same time, it provides a possibility to 
obtain additional information from the analysis of data on dynamics of the abundance (or other important parameter) of the studied population.

Therefore, the analysis of dynamic phase portraits significantly facilitates the periodization of naturalization of an introduced species, which allows one to detect changes in its population characteristics at each stage of this process. During the absence of limiting influence of the environment on the population, an increase in its abundance is observed (Odum, 1971; Pianka, 1978; Solbrig \& Solbrig, 1979). In nature, such a situation can be seen during the first years of formation of a population at the III stage of naturalization. In fact, in most cases maximum specific rates of growth of the population of introduced species are characteristic particularly for the III phase. However, the analysis of dynamic phase portraits of short-cycle species (sprat, smelt) demonstrated that in a number of cases the highest specific rates of changes can be also realized after the population of introduced species transitions into the regime of fluctuation of its abundance (IV phase of naturalization, Table 1). In this case, maximum values of growth were observed in the period of restoration of population after catastrophic decline (Tereshchenko et al., 2015; Tereshchenko \& Tereshchenko, 2017).

Taking into account the results, we succeeded in detecting a tendency towards reduction of the potential rate of growth of the population of sprat during the process of its colonisation of the Dnieper and Volga reservoirs. Therefore, sprat in the Kahovka Reservoir had a higher value of this parameter than in the populations of the Dneprodzerzhynsk and Kremenchyg reservoirs, by 2.9 and 1.8 times respectively (Table 2 ). A similar tendency was observed in the reservoirs of the Volga cascade. This is, probably, related to the effect of temperature conditions of the water reservoir both on the efficiency of reproduction of introduced species and the development of the food base. However, for populations of smelt (Osmerus eperlanus), a cold-loving species, decrease in the potential speed of growth was observed in a southward direction. In this case, we see that increase in the vegetative period and food base does not compensate the reduction of the effectiveness of reproduction. The highest potential rate of the natural growth of population of the studied species was noted in the southern populations of Black Sea sprat and stone moroko (Pseudorasbora parva).

We should note that potential rate of growth of population allows one to compare the efficiency of species as introduced elements of an ecosystem. Therefore, in the Rybinsk Reservoir the northernmost population of Black Sea sprat has formed, and the population of smelt is near its native range (Lake Beloe). And though the density of concentrations of sprat in this water body is lower compared with the smelt, taking into account the dynamic properties of populations, it can be characterized as the more efficient introduced species which can potentially have a more significant effect on the ecosystem compared with that of smelt (Slynko \& Tereshchenko, 2014).

Table 2

Potential speed of growth of populations

of species colonizing reservoirs in the Pontic-Caspian Basin

\begin{tabular}{|c|c|c|c|c|}
\hline Species & $\begin{array}{c}\text { Water } \\
\text { reservoir }\end{array}$ & $\begin{array}{l}\text { Latitude, } \\
{ }^{\circ} \mathrm{N}\end{array}$ & $\begin{array}{l}\text { Potential rate of } \\
\text { growth, year }^{-1}\end{array}$ & Source \\
\hline \multirow{2}{*}{$\begin{array}{l}\text { Stone moroko } \\
\text { (Pseudorasbora } \\
\text { parva) }\end{array}$} & Kremenchuk & 49 & 2.6 & \multirow{2}{*}{$\begin{array}{l}\text { Tereshchenko et al., } \\
2017\end{array}$} \\
\hline & Kamianske & 48 & 3.5 & \\
\hline \multirow{2}{*}{$\begin{array}{l}\text { Smelt (Osmerus } \\
\text { eperlanus) }\end{array}$} & Rybinsk & 58 & $4.2^{*}$ & \multirow{2}{*}{$\begin{array}{l}\text { Tereshchenko \& } \\
\text { Tereshchenko, } 2017\end{array}$} \\
\hline & Kuybyshev & 55 & 3.7 & \\
\hline \multirow{2}{*}{$\begin{array}{l}\text { Black-striped pipe- } \\
\text { fish (Syngnathus } \\
\text { abaster) }\end{array}$} & - Kremenchuk & 49 & 1.3 & \multirow{2}{*}{$\begin{array}{l}\text { Tereshchenko et al., } \\
2016\end{array}$} \\
\hline & Kamianske & 48 & 1.6 & \\
\hline \multirow{5}{*}{$\begin{array}{l}\text { Black Sea sprat } \\
\text { (Clupeonella } \\
\text { cultriventris) }\end{array}$} & Kakhovka & 46 & 4.9 & \multirow{5}{*}{$\begin{array}{l}\text { Tereshchenko et al., } \\
2015 \\
\text { Slynko \& } \\
\text { Tereshchenko, } 2014\end{array}$} \\
\hline & Kremenchuk & 49 & 2.7 & \\
\hline & Kamianske & 48 & 1.7 & \\
\hline & Kuybyshev & 55 & 3.6 & \\
\hline & Rybinsk & 58 & $3.2^{*}$ & \\
\hline
\end{tabular}

Note: *-maximum specific rate of the growth of population at the IV phase of naturalization.

Use of the method of dynamic phase portrait allows one to obtain new information which would otherwise remain hidden in the course of conventional research. Therefore, analysis of trajectory of change of catches of zander in Lake Vozhe (Fig. 3) revealed at least two periods of reduction of the speed of changes in the number of caught fish (19971999 and 2001). The following analysis demonstrated decrease in the population of zander hatched in the years 1997-1999, which gave a reason to presume that over this period, density-regulating mechanisms were activated. One of them is emigration of some individuals from the high density regions (Ricklefs, 1976). Really, according to observations of ichthyologists, zander from Lake Vozhe have already entered Lake Lacha and the basin of the Onega, where they were not found earlier (Novoselov, 2003).

Finally, the analysis of dynamic portrait allows one to look at the changes in structural-functional characteristics from a new angle. The possibility of distinguishing qualitatively different conditions of population (period of its transition from one condition into another and period of being in equilibrium state) relieves the researcher of the need to attempt to detect a general tendency in the change of population parameters in the periods when it was absent, because during the period of observations it was in different states. Furthermore, it provides possibility of assessment of time of a population's exit from the equilibrium state even in cases when the start of the transition is beyond the limits of the observation periods.

Therefore, it was shown that developments of the Middle-Timan bauxite deposit at the current stage had practically no effect on the condition of the habitat of fish in the local ecosystems. However the development of the system of transport communications led to a significant increase in the number of people fishing. As a result the population of grayling (Thymallus thymallus), which dominated in the Vym River, transitioned to the state of lower abundance, and the fish population of the watercourse - to the state with lower level of diversity (Boznak et al., 2019). The initial non-specific adaptive reaction of the fish community was observed during eutrophication of the lakes (Tereshchenko et al., 2004), increase in their thermal (Tereshchenko et al., 2007) and toxic pollutions (Reshetnikov et al., 2011). Thus, all series of observations can be distinctively designated into two periods: restructurisation of the population (2005-2007) and being in the state of equilibrium in 2007-2016. Analysis of the dynamic phase portrait allows one to draw the conclusion that at the beginning of systematic observations (2005) the population of grayling was already at the stage of restructurisation, after exiting the previous steady state. As we know, the phase portrait describes the dynamics of the system with a parabola (Ailamazyan \& Stas', 1989). Because the parabola is a symmetric figure, this enables one to determine temporal boundaries of the exit of a population from the previous steady state. In 2005 the rate of change in the abundance of the grayling population (by module) was at its maximum, and it had entered in the equilibrium condition by 2007 . Therefore, we can conclude that the population left its previous equilibrium state in the early 2000s. The obtained results allow also more correct description of the changes occurring in the age structure of the population, uniting data which characterize the grayling population in the Vym River during the period when it was in the two consequent equilibrium states (1996-2002 and 2010-2016). It was found that during transition of the population into a new state with low level of population, decrease in the maximum age, reduction of the number of age groups, and rejuvenation of modal age class were observed (Zakharov \& Cherezova, 2008; Zakharov \& Boznak, 2011). Such changes in the age structure are equivalent to the restructurisation of the population of grayling from long-cycle to average-cycle type of functioning (Zinov'yev, 2005). Similar changes in the structure of fish population, which occur under the impact of intense fishing, are well known (Nikol'skii, 1974; Ricker, 1975).

Thus, the method of dynamic phase portrait allows one to detect equilibrium levels of functioning of populations, and also the extent of their deviation from these zones. At the same time, behaviour of populations in the equilibrium zones, described in the terms and formulae of this method, complement well the general patterns of behaviour of biological systems.

In the absence of significant impacts, the presence of negative reversible relations leads to stabilization of a supra-organism system, and its exit from the equilibrium state indicates intensification of the disruptive effect (Schmalhausen, 1968). The abundance of a population is regulated by the balance between the two positive tendencies characteristic of populations potential for growth and limitations imposed on this growth by the environment. The capability of the environment to support a species depends on the climate and presence of resources, and thus the equilibrium density of the population of a given species also varies (Ricklefs, 1976). 


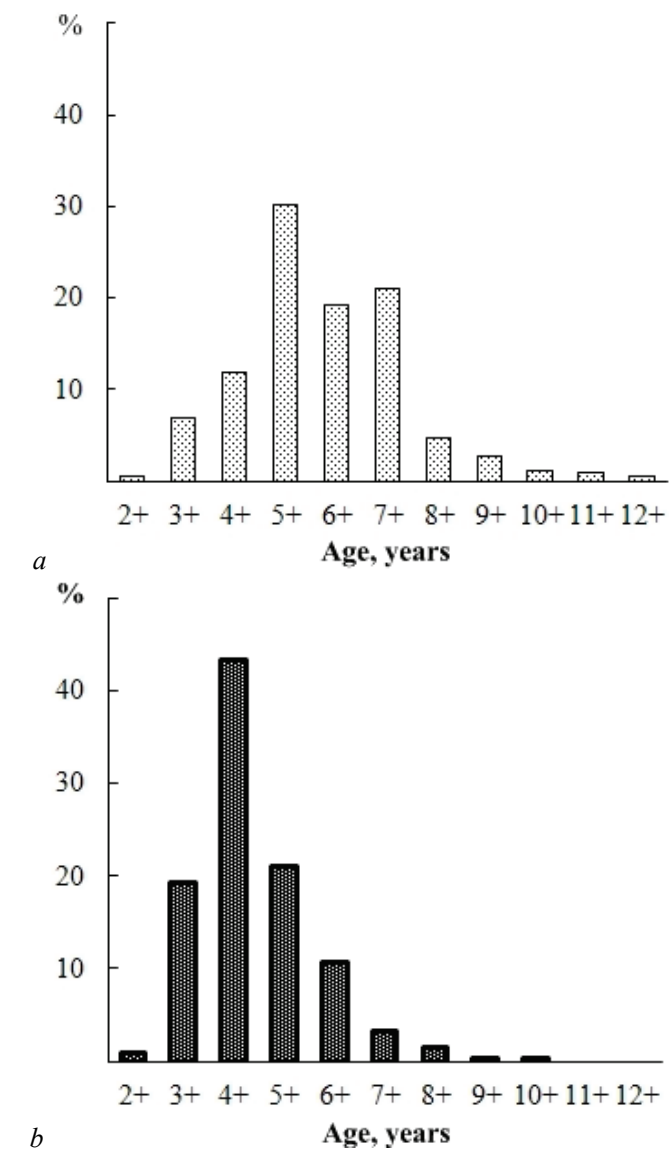

Fig. 5. Age structure of the grayling population in the upstream Vym River in equilibrium states, which existed in 1996-2002 (a) and in 2010-2015 (b) according to Boznak et al. (2019)

\section{Conclusions}

The example of fish demonstrates that the dynamic phase portrait is an effective method of analysis of changes which occur in the populations of animals.

Behaviour of populations in the equilibrium zones, described in the terms and formulae of this method complement well the wellknown general patterns of behaviour of biological systems.

Use of the dynamic phase portrait does more than visualise the changes in populations of animals. This method, first of all, makes it possible to reveal the equilibrium states, time of exiting them, determine density of population at which intrapopulational mechanisms of reducing the number activate, and analyze more correctly both the dynamic of abundance of population and separate parameters - age structure, rate of maturation, etc.

This work was carried out within the framework of state project No AAA-A18118012690102-9 and No AAAA-A17-117112850235-2, with partial financial support from a grant of RFBR 18-44-160023p_a.

\section{References}

Ailamazyan, A. K., \& Stas', E. V. (1989). Informatika i teoriya razvitiya [Information science and the theory of development]. Nauka, Moscow (in Russian).

Antamonov, Y. G. (1977). Modelirovaniye biologicheskikh sistem [Biological systems modeling]. Naukova Dumka, Kiev (in Russian).

Begon, M., Harper, J. L., \& Townsend, C. R. (1986). Ecology: Individuals, populations and communities. Blackwell Scientific Publications, Oxford.

Birch, L. C. (1948). The intristic rate of natural increase of an insect population. Journal Animal Ecology, 17, 15-26.

Bobretsov, A. V. (2009). Dinamika chislennosti krasnoy polevki (Clethrionomys rutilus, Rodentia) v Severnom Predural'ye za poluvekovoy period [Dynamics of the number of red vole (Clethrionomys rutilus, Rodentia) in the Northern Urals for a half-century period]. Zoologichesky Zhurnal, 88(9), 1115-1126 (in Russian).

Bolotova, N. L., Zuyanova, O. V., Zuyanov, Y. A., \& Shitova, S. V. (1995). Akklimatizatsiya sudaka i vklyucheniye yego $\mathrm{v}$ sistemu pishchevykh otnosheniy ozera Vozhe [Acclimatization of pike perch and its inclusion in the food system of Lake Vozhe]. Journal of Ichthyology, 35(3), 374-387 (in Russian).

Boonstra, R., \& Krebs, C. J. (2011). Population dynamics of red-backed voles (Myodes) in North America. Oecologia, 168(3), 601-620.

Boznak, E. I., Zakharov, A. B., \& Tereshchenko, V. G. (2019). Effect of the increasing intensity of recreational fishing on the fish assemblage of a watercourse in an economic development zone. Inland Water Biology, 12(1), 88-95.

Clarke, K. R., \& Warwick, R. M. (1998). Quantifying structural redundancy in ecological communities. Oecologia, 113(2), 278-289.

Dorovskikh, G. N., Tereshchenko, V. G., \& Stepanov, V. G. (2012). Kolichestvennyy analiz sezonnoy dinamiki vidovoy struktury komponentnogo soobshchestva parazitov gol'yana Phoxinus phoxinus (L.) iz reki Pechora [Quantitative analysis of seasonal dynamics of the species structure in a component parasite community of the minnow Phoxinus phoxinus (L.) of the Pechora River]. Parazitologiva, 46(2), 111-117 (in Russian).

Dorovskikh, G. N., Tereshchenko, V. G., \& Stepanov, V. G. (2016). Sezonnaya dinamika vidovoy struktury komponentnogo soobshchestva parazitov yersha iz reki Vychegda [Seasonal dynamics of the species structure of the component parasitic community of the ruff in Vychegda River]. Parazitologiya, 50(1), 58-68 (in Russian).

Gerasimov, Y. V. (2005). Dinamika raspredeleniya ryb v Rybinskom vodokhranilishche [Dynamics of fish distribution in the Rybinsk reservoir]. In: Actual problems of rational use of biological resources of reservoirs. Rybinsk, 46-58 (in Russian).

Gerasimov, Y. V., Brazhnik, S. Y., \& Strelnikov, A. S. (2010). Dynamics of structural parameters of populations of the bream Abramis brama (Cyprinidae) in Rybinsk Reservoir in 1954-2007. Journal of Ichthyology, 50(6), 465-474.

Gerasimov, Y. V., Strel'nikov, A. S., \& Ivanova, M. N. (2013). Dynamics of structural indices of populations of zander Stizostedion lucioperca (Percidae) of the Rybinsk Reservoir for 1954-2010. Journal of Ichthyology, 53(1), 41-51.

Gilpin, M. E., Case, T. J., \& Bender, E. A. (1982). Counterintuitive oscillations in systems of competition and mutualism. The American Naturalist, 119(4), $584-588$.

Inderjit, S., Cadotte, M. W., \& Colautti, R. I. (2005). The ecology of biological invasions: Past, present and future. In: Invasive plant: Ecological and Agricultural Aspects. Birkhäuser Verlag Switzerland, Basel. Pp. 19-43.

Karpevich, A. F. (1975). Teoriya i praktika akklimatizatsii vodnykh organizmov [Theory and practice of acclimatization of aquatic animals]. Pishchevaya Promyshlennost', Moscow (in Russian).

Kiyashko, V. I., \& Slynko, Y. V. (2003). Distribution of kilka in the Upper Volga reservoirs and determination of its trophic state under the new ecological conditions. In: Invasions of alien species in the Holarctic. Proceedings of US - Russia Invasive Species Workshop. 27-31 August, 2001. Borok, Russia. Pp. 259-271.

Kiyashko, V. I., Osipov, V. V., \& Slyn'ko, Y. V. (2006). Razmemo-vozrastnyye kharakteristiki i struktura populyatsii tyul'ki Clupeonella cultriventris (Nordmann, 1840) pri yeye naturalizatsii v Rybinskom vodokhranilishche [Dimensional age characteristics and population structure of kilka Clupeonella cultriventris (Nordmann, 1840) with its naturalization in the Rybinsk reservoir]. Joumal of Ichthyology, 46(1), 68-76 (in Russian).

Mineeva, N. M., \& Tereshchenko, V. G. (2013). Application of the phase portrait method for analysis of seasonal dynamics in phytoplankton productivity in a large plain reservoir. Inland Water Biology, 6(1), 70-79.

Nikol'skii, G. V. (1974). Teoriya dinamiki stada ryb kak biologicheskaya osnova ratsional'noi ekspluatatsii i vosproizvodstva rybnykh resursov [The theory of the fish school dynamics as a biological basis of sustainable use and reproduction of fish resources]. Pishchevaya Promyshlennost', Moscow (in Russian).

Novoselov, A. P. (2003). K voprosu o poyavlenii chuzherodnykh vidov ryb v basseyne Belogo moray [On the question of the emergence of alien species of fish in the White Sea basin]. In: Biologichesiye resursy Belogo morya i vnutrennikh vodoyemov Yevropeyskogo Severa. Tezisy dokladov. Syktyvkar. P. 61 (in Russian).

Odum, E. P. (1971). Fundamentals of ecology. 3rd ed. WB Saunders Company, Philadelphia, London, Toronto.

Pianka, E. R. (1978). Evolutionary ecology. Harper and Row, New-York, Hagerstown, San Francisco, London.

Polovkova, S. N., Tereshchenko, V. G., Tereshchenko, L. I., \& Nadirov, S. N. (2007). Changes in the species structure of fish population of sapropelic Lake Nero. Hydrobiological Journal, 43(3), 57-70

Portrait, V., Gendron-Gaillard, S., Cottenceau, G., \& Pons, A. M. (1999). Inhibition of pathogenic Salmonella enteritidis growth mediated by Escherichia coli microcin J25 producing strains. Canadian Journal of Microbiology, 45(12), 988-994

Reshetnikov, Y. S., Tereshchenko, V. G., \& Lukin, A. A. (2011). Dinamika rybnoy chasti soobshchestva $v$ izmenyayushchikhsya usloviyakh sredy obitaniya (na primere ozera Imandra) [The dynamics of the fish part of the 
community in changing habitat conditions (using the example of Lake Imandra)]. Rybnoye Khozyaystvo, 6, 48-52 (in Russian).

Ricker, W. E. (1975). Computation and interpretation of biological statistics of fish populations. , Bulletin 191. Fisheries Research Board of Canada, Ottawa.

Ricklefs, R. E. (1976). The economy of nature. A textbook in basic ecology. Chiron Press Inc., Portland.

Romanovsky, Y. M., Stepanova, N. V., \& Chemavsky, D. S. (1975). Matematicheskoye modelirovaniye $\mathrm{v}$ biofizike [Mathematical modeling in biophysics]. Nauka, Moscow (in Russian).

Rozenfeld, S. B., \& Sheremetyev, I. S. (2016). Arkticheskiye gusi (Anser) i kazarki (Branta) Yevrazii: Analiz faktorov dinamiki chislennosti i arealov [Arctic geese (Anser) and brants (Branta) of Eurasia: An analysis of factors that control population dynamics and geographical ranges]. Journal of General Biology, 77(1), 16-37 (in Russian).

Seip, K. L. (1997). Defining and measuring species interactions in aquatic ecosystems. Canadian Journal of Fisheries and Aquatic Sciences, 54(7), 1513-1519.

Schmalhauzen, I. I. (1968). Integratsiya biologicheskikh sistem i ikh samoregulyatsiya [Integration of biological systems and their self-regulation]. In: Kiberneticheskiye voprosy biologii. Nauka, Novosibirsk. Pp. 157-183 (in Russian).

Slynko, Y. V., \& Kiyashko, V. I. (2012). Analysis of effectiveness of pelagic fish species invasions into the Volga River reservoirs. Russian Journal of Biological Invasions, 3(2), 129-138.

Slynko, Y. V., \& Tereshhenko, V. G. (2014). Ryby presnykh vod Ponto-Kaspijskogo bassejna (raznoobrazie, faunogenez, dinamika chislennosti, mekhanizmy adaptatsii) [Freshwater fishes of the Ponto-Caspian basin (diversity, faunogenesis, population dynamics, adaptation mechanisms)]. Poligraf-Plyus, Moscow (in Russian).

Solbrig, O. T., \& Solbrig, D. J. (1979). Introduction to population and evolution. Addison-Wesley Publishing Company, Reading, Massachusetts, Menlo Park.

Svirizhev, Y. M., \& Logofet, D. O. (1978). Ustoichivost' biologicheskikh soobshchestv [Stability of biological communities]. Nauka, Moscow (in Russian).

Tereshchenko, V. G., \& Strelnikov, A. S. (1995). Analysis of changes in the fish component of the Lake Balkhash community as a result of introduction of the new fish species. Journal of Ichthyology, 35(1), 90-98.

Tereshchenko, V. G., \& Strelnikov, A. S. (1997). Analysis of long-term changes in the fish part of community in the Rybinsk reservoir. Journal of Ichthyology, 37(8), 590-598.

Tereshchenko, V. G., \& Tereshchenko, L. I. (2004). Vliyaniye izmeneniya urovnya krupnogo melkovodnogo ozera na strukturu yego rybnogo naseleniya (na primere oz. Ubinskogo) [The effect of water level fluctuations in the Large Shallow Ubinskoe Lake on the structure of its fish community]. Biology of Inland Waters, 1, 80-87 (in Russian).

Tereshchenko, V. G., \& Tereshchenko, L. I. (2017). Potentsial'naya skorost' rosta chislennosti populyatsiy snetka Osmerus eperlanus eperlanus (L.) Kuybyshevskogo vodokhranilishcha [Specific growth rate of smelt Osmerus eperlanus (L.) population in Kuibyshev reservoir]. Transactions of IBIW RUS, 80(83), 86-94 (in Russian).

Tereshchenko, V. G., \& Verbitsky, V. B. (1997). Metod fazovykh portretov dlya analiza dinamiki struktury soobshchestv gidrobiontov [The method of phase portraits for analyzing the structural dynamics of hydrobiont communities]. Biology of Inland Waters, 1, 23-31 (in Russian).
Tereshchenko, V. G., \& Zuyanova, O. V. (2006). The method of assessment of relative abundance of commercial fish species generations under conditions of incomplete initial information. Biology of Inland Waters, 1, 88-92.

Tereshchenko, V. G., Buzevich, I. Y., Khrystenko, D. S., \& Tereshchenko, L. I (2015). Specific growth rate of Kilka Clupeonella cultriventris (Nordmann, 1840) populations in Dneprodzerzhinsk and Kremenchug reservoirs at different phases of its naturalization. Inland Water Biology, 8(3), 301-308.

Tereshchenko, V. G., Kapusta, A., Wilkonska, H., \& Strelnikova, A. P. (2007). Long-term chages in 0+ fish assemblages in the litoral zone of heated lakes. 1. Using phase diagrams to evaluated changes in ichthyofauna. Archives of Polish Fisheries, 15(4), 415-430.

Tereshchenko, V. G., Khrystenko, D. S., Kotovska, G. O., \& Tereshchenko, L. I (2016). Characteristics of stone moroko population dynamics at different stages of naturalization in lake- and steam-type Dnieper reservoirs. Russian Journal of Ecology, 47(4), 364-370.

Tereshchenko, V. G., Khrystenko, D. S., Kotovska, G. O., \& Tereshchenko, L. I (2016). The specific rate of the population dynamics of the black-striped pipefish Sygnathus nigrolineatus Eichwald, 1831 in the Kremenchug and Dneprodzerzhinsk reservoirs at different phases of the natu-ralization of the species. Inland Water Biology, 9(1), 79-86.

Tereshchenko, V. G., Sterligova, O. P., Pavlov, V. T., \& Il'mast, N. V. (2004). Mnogoletnyaya dinamika strukturnykh i sistemnykh kharakteristik rybnogo naseleniya evtrofiruyemogo Syamozera [Long-term dynamics of structural and system characteristics of the fish population of eutrophicated Syamozero]. Biology of Inland Waters, 3, 93-102 (in Russian).

Tereshchenko,V. G., \& Nadirov, S. N. (1996). Formation of fish population structure in the foot-hill reservoir. Journal of Ichthyology, 36(2), 146-152.

Verbitskii, V. B., \& Tereshchenko, V. G. (1996). Structural phase diagrams of animal communities in assessment of freshwater ecosystem conditions. Hydrobiologia, 322, 277-282.

Vol'kenshtein, M. V. (1978). Obshchaya biofizika [General biophysics]. Nauka, Moscow (in Russian).

Voronov, D. A. (2005). Raschet udel'noy skorosti rosta populyatsii: Sopostavlenie opredeleniya i modeli [Calculation of the specific growth rate of a population: Comparison definition with model]. Jornal of General Biology, 66(5), 425-430 (in Russian).

Zakharov, A. B., \& Boznak, E. I. (2011). Sovremennoye sostoyaniye rybnogo naseleniya vodotokov Timana [The current state of the fish population of the Timan watercourses]. In: Sovremennoye sostoyaniye bioresursov vnutrennikh vodoyemov. Materialy dokladov I Vserossiyskoy konferentsii s mezhdunarodnym uchastiyem. Akvaros, Moscow. Pp. 243-250 (in Russian).

Zakharov, A. B., \& Cherezova, M. I. (2008). Ikhtiofauna malykh vodotokov v rayone razrabotki boksitovykh mestorozhdeniy Timana [Ichthyofauna of small streams in the area of development of bauxite deposits in Timan]. In: Raznoobrazie i prostranstvenno-ekologicheskaya organizatsiya zhivotnogo naseleniya evropeiskogo Severo-Vostoka. Komi Nauchnyi Tsentr, Syktyvkar. Pp. 54-80 (in Russian).

Zinov'yev, Y. A. (2005). Ekologiya i sistematika khariusovykh ryb Yevrazii [Ecology and systematics of grayling fishes of Eurasia]. Perm (in Russian). 